\title{
O migracijah v šoli: od izseljensko- priseljenske perspektive do življenjskih zgodb
} Marjanca Ajša Vižintin

\section{Uvod}

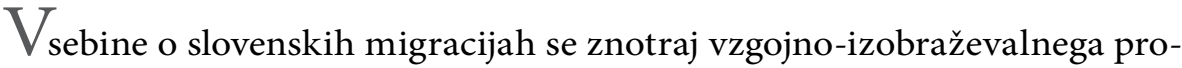
cesa premalo ali skoraj nič ne obravnavajo, čeprav je bila Slovenija v 20. stoletju tako dežela izseljevanja kot dežela priseljevanja. ${ }^{I}$ Tako je tudi na začetku 21. stoletja, ljudje se iz Slovenije izseljujejo in ljudje se v Slovenijo priseljujejo. Koliko izvedo otroci v osnovnih ali srednjih šolah o sodobnih migracijah in o slovenski zgodovini, tesno prepleteni z izseljevanjem in priseljevanjem (Lukšič Hacin, 1995, 2018; Kobolt, 2002; Komac, 2007; Kalc, Milharčič Hladnik, Žitnik Serafin, 2020)? Pa o Slovenkah, Slovencih kot prebežnikih po prvi in drugi svetovni vojni v 2o. stoletju (Milharčič Hladnik, 2020)? O spremenjenih državnih mejah po obeh vojnah, katere posledice so mdr. manjšine na obeh straneh meje? Koliko se pri slovenščini, angleščini in drugih jezikih spregovori o odnosu do maternega jezika, večletnem učenju jezika okolja po preselitvi? Se pri pouku književnosti bere književna besedila, ki so jih napisale pripadnice, pripadniki manjšin

1 Prispevek je nastal v okviru raziskovalnega programa »Narodna in kulturna identiteta slovenskega izseljenstva v kontekstu raziskovanja migracij« ( $\left.\mathrm{P}_{5}-0070\right)$, temeljnega raziskovalnega projekta »Socialna, gospodarska in kulturna zgodovina slovenskega izseljenstva (1945-91) «(J5-8246) in aplikativnega projekta »Le z drugimi smo« (C3330-16-269110). Financirajo jih Javna agencija za raziskovalno dejavnost Republike Slovenije, Ministrstvo za izobraževanje, znanost in šport Republike Slovenije, Evropski socialni sklad.
\end{abstract}


ali priseljenke, priseljenci v Sloveniji (Žitnik, Glušič 1999; Dimkovska, 2014; Vižintin, 2016a, 2018a)? Se pri družbi, zgodovini, geografiji, sociologiji, filozofiji, psihologiji učenke, učenci soočajo z izzivi vključevanja novopriseljenih, s soodgovornostjo vseh pri večletnem procesu vključevanja (Vižintin 2017)? Koliko razmisleka so deležne učenke, učenci o sestavljeni identiteti, spreminjajoči se kulturi, o oblikovanju nacionalnih držav kot zamišljenih skupnosti (Anderson, 1998; Sedmak, 2011; Milharčič Hladnik, 2015)? Koliko so tovrstne vsebine vpete $\mathrm{v}$ univerzitetno izobraževanje, ki pripravlja bodoče učiteljice, učitelje na večkulturne, večjezične, večverske razrede? Ali jih?

Zagotovo bi se migracijske vsebine pri pouku obravnavale več, če bi bile del učnih načrtov in gradiv (Vižintin, 2018b). Učiteljice, učitelji bi ob obravnavi učnih ciljev, povezanih s slovenskimi ilegalnimi in legalnimi migracijami v različnih časovnih obdobjih in $\mathrm{v}$ različne države odpirali številna vprašanja o migracijah kot stalnici - obenem pa bi tovrstne izkušnje povezali s sodobnimi migracijami, tako ekonomskimi kot begunskimi. Slednje so pogosto ilegalne, saj so legalne možnosti prosilkam, prosilcem za mednarodno zaščito v 21. stoletju v Evropi vedno manj dostopne.

\section{Namen in cilji}

Namen prispevka je opozoriti na možno in potrebno obravnavo migracijskih vsebin znotraj pouka, pri čemer je pomembna priseljensko-izseljensko perspektiva: izseljenci, izseljenke iz Slovenije so v neki drugi državi priseljenci in priseljenke. Verjamem, da bi obravnava slovenskih migracij, ki so vpete $\mathrm{v}$ širše družbene tokove $\mathrm{v}$ drugih državah in na drugih celinah, prispevala k razumevanju migracij kot stalnici v človeški zgodovini, v sedanjosti pa k uspešnejšemu vključevanju (otrok) priseljencev in prijaznejši podpori novopriseljenim. Cilj prispevka je opozoriti na kompleksnost migracijskih procesov, izhajajoč iz osebne življenjske zgodbe ter upoštevajoč družbeno-politične razmere v izvorni in sprejemni državi v določenem času. Na podlagi predstavljene življenjske zgodbe želi prispevek spodbuditi učiteljice, učitelje, da v svojem šolskem, lokalnem okolju s svojimi učenci, učenkami poiščejo njihove življenjske zgodbe.

Življenjske zgodbe sestavljajo biografska in avtobiografska besedila, objavljena $\mathrm{v}$ časopisih, revijah in knjigah ali spravljena $\mathrm{v}$ arhivih; pričevanja, pripovedi in osebni spomini ali spomini potomcev; ter osebni dokumenti, kot so fotografije, dnevniki, pisma ali razglednice. Ti viri so »dragocena skladišča individualnega spomina« (Verginella 2004), pri čemer je pomembno, da so v njih zbrane interpretacije in subjektivne izkušnje lju- 
di, ki niso izbranci političnih, vojaških in nacionalnih zgodovin in niso staljeni v številčnih izračunih kvantitativne metodologije (Milharčič Hladnik 2020: 367 v Kalc, Milharčič Hladnik, Žitnik Serafin 2020).

Premalo se zavedamo, da na osebne odločitve za selitve vplivajo tudi družbeno-politične razmere v izvorni in sprejemni državi, npr. meddržavne pogodbe o zaposlovanju delavcev (t. i. ekonomske migracije) ali vojne, ki sprožajo večje premike ljudi, bežečih pred nasiljem, strahom pred smrtjo in željo, da sebi in svojim otrokom omogočijo varnejši jutri (t. i. begunci). Čeprav predlagam pri raziskovanju in razumevanju migracij uporabo življenjskih zgodb, kar je del kvalitativne metodologije, menim, da je potrebno tudi poznavanje uradnih (statističnih) podatkov. To ponuja učiteljicam, učiteljem in njihovim učenkam, učencem druge možnosti raziskovanja in pridobivanja (številčnih) dejstev o sodobnem priseljevanju v Slovenijo in izseljevanju iz nje. Skupaj s kombinacijo osebnih življenjskih zgodb in $s$ (s)poznavanjem družbeno-političnih razmer v izvorni in sprejemni državi tako postane podoba (slovenskih) migracij bližja realnosti. ${ }^{2}$

\section{Sodobne slovenske migracije v številkah}

Kot dodaten izziv za raziskovanje sodobnih migracij predstavljam nekaj statističnih podatkov. Od leta 2010 do leta 2017 so si številke izseljenih in priseljenih migrantk, migrantov zelo podobne (Tabela 15), podobna pa je tudi izobrazba priseljenih in izseljenih leta 2017. Najpogostejši razlog za priselitev v Slovenijo leta 2017 niso bile vložene prošnje za mednarodno zaščito, ampak zaposlitev in združevanje družine. Število prošenj za mednarodno zaščito (t. i. azil) je nizko, še manjše pa je število odobrenih prošenj (Slika 3).

Tabela I5: Število priseljenih v Slovenijo in izseljenih iz Slovenije (20I0-20I7).

\begin{tabular}{lcccccccc} 
& 2010 & 2011 & 2012 & 2013 & 2014 & 2015 & 2016 & 2017 \\
$\begin{array}{l}\text { Priseljenci } \\
\text { iz tujine }\end{array}$ & 15.416 & 14.083 & 15.022 & 13.871 & 13.846 & 15.420 & 16.623 & 18.808 \\
\hline $\begin{array}{l}\text { Odseljeni } \\
\text { v tujino }\end{array}$ & 15.937 & 12.024 & 14.378 & 13.384 & 14.336 & 14.913 & 15.572 & 17.555 \\
\hline
\end{tabular}

Vir: Selitveno gibanje, Slovenija, 2017; Socioekonomske značilnosti meddržavnih selivcev, Slovenija, 2017.

2 O prepletanju in sovplivanju vseh teh dejavnikom smo spregovorili tudi na usposabljanjih Le $z$ drugimi smo (2016-2021), ko je enemu od petih 16-urnih seminarjev prisluhnilo več kot 10.000 pedagoških delavk, delavcev po vsej Sloveniji in v zamejstvu. 
Leta 2017 je imela več kot polovica priseljenih $(58,7 \%)$ in izseljenih (53,6 \%) prebivalcev, starih 15 let ali več, srednješolsko izobrazbo. Četrtina priseljenih (25,6\%) in malo manj kot četrtina izseljenih $(22,8 \%)$ je imela osnovnošolsko izobrazbo. Med priseljenimi je imela terciarno izobrazbo manj kot petina prebivalcev $(15,7 \%)$ in skoraj četrtina izseljenih $(23,6 \%)$. Mit o tem, „da se izseljujejo samo visoko izobraženi, priseljujejo pa samo neizobraženi«, torej ne drži. Res pa je, da je prirast terciarno izobraženih negativen: leta 2017 se je iz Slovenije izselilo več terciarno izobraženih, kot se jih priselilo, razlika je - 1.063 terciarno izobraženih (prim. Vižintin, Lukšič Hacin, Gostič 2020).

V letu 2017 se je po podatkih SURS-a v Slovenijo priselilo 18.808 prebivalcev, od tega je bilo 15.520 tujih / drugih državljank, 3.288 pa slovenskih. Od 15.520 v letu 2017 v Slovenijo priseljenih tujih državljank se jih je največ priselilo $\mathrm{z}$ namenom zaposlitve ( $55 \%$ ). Veliko se je priselilo tudi $\mathrm{z}$ namenom, da se pridružijo svojim družinskim članom (36\%), študij (3\%) in drugi razlogi so bili redkejši (Selitveno gibanje, Slovenija, 2017; Socioekonomske značilnosti meddržavnih selivcev, Slovenija, 2017).

\section{Število oseb s priznano mednarodno zaščito v Republiki Sloveniji po letih}

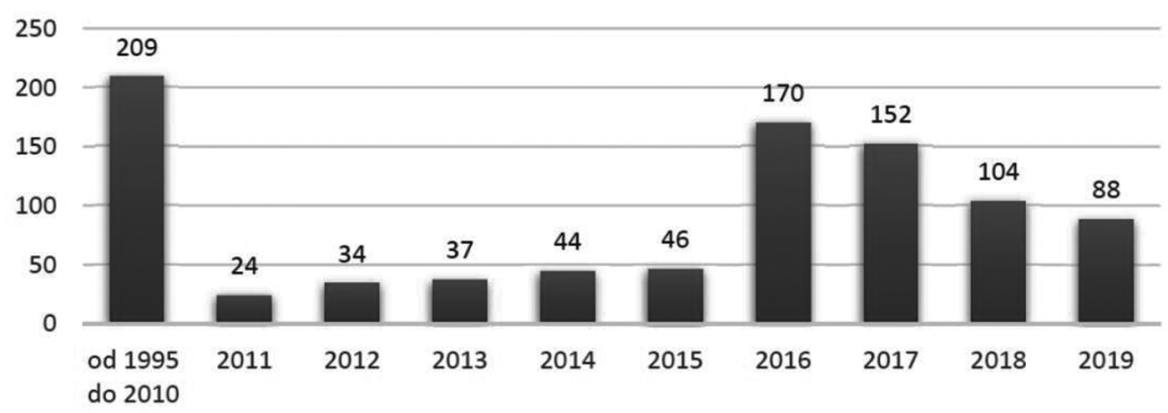

Slika 3: Število oseb s priznano mednarodno zaščito v Republiki Sloveniji (1995-2019) Vir: Osebe s priznano mednarodno zaščito po letih (2020).

Za nekoliko daljše časovno obdobje je prikazano število odobrenih prošenj za mednarodno zaščito. Število prosilk, prosilcev je bilo precej večje kot število odobrenih prošenj. ${ }^{3}$ Izbrana leta in števila so vabilo, da se raziščejo tudi druga leta. Posredovani podatki o sodobnih migracijah so jav-

3 Številke prosilcev, prosilk za obdobje 2010-2019: 2010 (246), 2011 (358), 2012 (304), 2013 (272), 2014 (385), 2015 (277), 2016 (1308), 2017 (1476), 2018 (2875), 2019 (3821). 
no dostopni na spletnih straneh Statističnega urada Republike Slovenije, vsakdo se lahko prijavi na njihove brezplačne e-novice, in Urada Vlade Republike Slovenije za oskrbo in integracijo migrantov.

\section{Slovenci na Švedskem}

V slovenskem prostoru so v drugi polovici 20. stoletja bolj znane ekonomske migracije v Nemčijo, ki naj bi bile začasne, a so se za večino spremenile v trajne (Zupančič, 2001; Lukšič Hacin, 2018; Vižintin, 2016b). Nemčija je že od 19. stoletja ena od najbolj priljubljenih destinacij za slovenske ekonomske migrantke, migrante (Drnovšek, 2012), v tem prispevku pa se osredotočam na izseljevanje na Švedsko in na slovensko izseljensko zgodbo, ki se je začela $\mathrm{z}$ ilegalno migracijo.

Švedska je bila med drugo svetovno vojno nevtralna državna, po vojni pa je kot gospodarsko razvita država potrebovala delovno silo. Sporazum o socialni varnosti med Jugoslavijo in Švedsko je bil podpisan leta 1969 in leta 1979 nadomeščen $z$ novim (Svetek 1985: 22). ${ }^{4}$ Slovenci so odhajali na Švedsko od začetka 6o. do začetka 70. let 20. stoletja, pozneje pa so se tja selili posamezniki. Iz Slovenije se je na Švedsko preselilo od šest do sedem tisoč ljudi, nekaj se jih je vrnilo, številni pa so si na Švedskem ustvarili družine in imajo danes že vnuke. Naselili so se predvsem na jugu Švedske, a razpršeno, $v$ industrijskih središčih in obmorskih mestih, v katerih so potrebovali ljudi za delo v ladjedelnicah. Medtem ko so se ekonomski migranti na »začasnem delu v tujini« v Nemčiji imenovali gostujoči delavci (Gastarbeiter), v Franciji tuji delavci (travailleurs étrangés), se je na Švedskem že uveljavil termin priseljenci (invandrare). V 6o. letih 20. stoletja Švedska še ni imela uradne priseljenske politike, ampak se je do priseljencev, pa naj je šlo za prebežnike ali ekonomske migrante, vedla kot do Švedov, dobili so namestitev in zaposlitev. Leta 1969 je bil formiran Državni zavod za priseljence (Statens Invandrarvek - SIV), ki se je obračal predvsem na osrednje priseljenske organizacije. Priseljenke, priseljenci so se začeli organizirati in ustanavljati priseljenske zveze po nacionalnem ključu. Ustanovljena je bila Jugoslovanska zveza, leta 1968 je začelo delovati prvo samostojno slovensko

4 Od leta 1950 do leta 1979 je Jugoslavija podpisala 17 dvostranskih sporazumov o socialni varnosti: s Francijo, z Luksemburgom, Belgijo, Nizozemsko, Češkoslovaško, Madžarsko, Bolgarijo, Veliko Britanijo, Poljsko, Italijo, Švico, Avstrijo, Švedsko, ZR Nemčijo, Nemško demokratično republiko, Norveško, Dansko; vsi sporazumi niso bili enaki, delavcem so zagotavljali različne stopnje socialne varnosti (Svetek 1985: 21-31). 
društvo Triglav v Landskroni. Do leta 1999 je bilo na Švedskem ustanovljenih skupaj 14 slovenskih društev (Lukšič Hacin, 1995, 2001; Budja, 2005).

Leto 1975 bilo prelomno, saj je švedski parlament potrdil glavna načela priseljenske politike (enakost, svobodna izbira in sodelovanje), čemur je sledila večja finančna pomoč društvom priseljencev. Podporo so dobile vse organizacije, ki so podpirale zbliževanje med priseljenci in Švedi. Istega leta je bilo organizirano prvo posvetovanje predstavnikov slovenskih društev na Švedskem v Stockholmu, na drugem posvetovanju (29. 5. 1976) so ustanovili Koordinacijski odbor slovenskih društev. Prvi festival je bil leta 1975 v Jönköpingu; najprej so potekali vsako leto, potem vsako drugo leto. Od leta 1990 naprej se festival imenuje Slovenska kulturna srečanja (Lukšič Hacin, 2001). Slovenska društva na Švedskem so se udeleževala tudi srečanj slovenskih društev zahodne Evrope: leta 1978 je bilo med 42 slovenskimi društvi po Evropi 11 švedskih (Pogačnik idr. 1978). Za slovenske kulturne in literarne ustvarjalce je bila na Švedskem izjemnega pomena revija Naš glas (1973-2001), objavljali so tudi v slovenskih revijah Rodna gruda, Naša Slovenija, Naša luč, v Slovenskem izseljenskem koledarju, na slovenski strani v Jugoslovanskem listu, v reviji Jedinstvo (Žitnik, Glušič 1999; Budja 2005).

Prvi tečaji za odrasle in dopolnilni sobotni pouk slovenščine za otroke so bili organizirani v društvenih prostorih, pozneje pa se je redni pouk slovenskega jezika za otroke preselil na švedske šole, saj je resolucija iz leta 1975, ki je uvedla multikulturalizem, uzakonila tudi pravico do poučevanja maternega jezika v šolah. Jezik so poučevali učitelji, ki jih je potrdila in zaposlila Švedska. Slovenski jezik so organizirali v vseh treh večjih mestnih regijah v krajih Stockholm, Göteborg, Malmö, Landskrona, Olofström, Helsingborg, Ängelholm, Alvesta, Växjöj, Nybr, Norrköping, Köping, Halmstadt. Leta 1977 je dopolnilni pouk slovenščine obiskovalo 132 od 255 slovenskih šoloobveznih otrok, leta 1987 je 17 učiteljev poučevalo 240 učencev (Lukšič Hacin 2001: 302-303). V šolskem letu 2019/20, ko je dopolnilni pouk slovenskega jezika in kulture poučevalo slovenske izseljence in njihove potomce, potomke 36 učiteljic, učiteljev v 19 evropskih državah, je bil pouk še vedno organiziran tudi na Švedskem: v krajih Stockholm in Gaavle ga je izvajala Danni Stražar (Dopolnilni pouk 2019/20).

Slovenska zveza na Švedskem, ustanovljena leta 1991 v Köpingu, izdaja od leta 1992 slovensko-švedsko Slovensko glasilo/Slovenska bladet in združuje vsa slovenska društva na Švedskem. Leta 2019 je bilo članov v slovenskih društvih na Švedskem 1.o61, sicer pa na Švedskem po podatkih Slovenske zveze na Švedskem živi okoli "5.00o Slovencev in njihovih potomcev 
prve, druge in tretje generacije«, je navedel predsednik Slovenske zveze na Švedskem Alojz Macuh (2020). Na Švedskem je leta 2019 delovalo deset slovenskih društev in ena katoliška misija (Hrastar 2019; Macuh 2020).

Slovenska društva so razpršena na prostoru $600 \mathrm{~km} 2$. Društva so $\mathrm{v}$ desetih mestih in $\mathrm{v}$ sedmih pokrajinah. Dejavnosti se $\mathrm{v}$ večini društev spreminjajo, vedno manj je srečanj, dejavnosti upadajo, izjema pa je seveda nekaj društev, kjer je znova veliko aktivnosti. Tako imamo v sklopu društev še vedno 2-3 pevske zbore, veliko različnih prostočasnih dejavnosti, šolo oziroma urice slovenskega jezika v dveh društvih ter eno likovno in balinarsko sekcijo. Vsako drugo leto organiziramo t. i. Slovensko srečanje vseh Slovencev in društev nekje na Švedskem. Srečanje poteka v sklopu praznovanja obletnice določenega društva ali pa v povezavi s kakšno drugo obletnico. $\mathrm{V}$ avgustu organiziramo mladinsko in balinarsko srečanje vseh generacij. Prav tako se Slovenci iz vseh društev za binkoštni praznik srečamo v središču Švedske v lepem, majhnem mestu Sv. Brigite, v Vadsteni. Člani upravnega odbora Slovenske zveze se srečujemo dvakrat na leto: $v$ mesecu marcu/aprilu na občnem zboru in novembra na jesenski konferenci. Delo slovenske zveze se nadaljuje, delamo in spoštujemo smernice, ki smo jih navajeni, prizadevamo si ohranjati slovensko besedo, ohranjamo medsebojne stike ter ne pozabljamo, da smo člani slovenskih društev in obenem člani slovenske zveze. Kot predsednik si želim, da si pomagamo in vztrajamo ter s skupnimi močmi ohranjamo slovensko besedo in kulturo. Želim vam veliko prijetnega počutja in pristnega veselja, hkrati pa želim tudi, da si s skupnimi moči skupaj še bolj prizadevamo za obstoj nas Slovencev na Švedskem in da svojega porekla in rodu ne bomo nikoli zatajili (Macuh 2020).

Posamezni slovenski (ekonomski) izseljenci, izseljenke se tudi v 21. stoletju selijo na Švedsko. Nekateri se z izseki iz svojih življenjskih zgodb pojavljajo v sodobnih slovenskih medijih, npr. plesalka in kulturna antropologinja Zala Pezdir (Nakrst, 2018); pevka Maja Keuc (Doljak, 2018); gradbena inženirka Maja Golubovič (Krivec, 2019). Tudi na Švedskem se slovenska društva pri novih slovenskih priseljencih spoprijemajo z izzivi nevključevanja v slovenska društva (kot v Nemčiji, prim. Vižintin, 2016), a nekateri se vključijo in prevzamejo aktivno vlogo. Med njimi je tudi Rok Ogrin 
(Hrastar 2018), priseljen na Švedsko leta 2012, zdaj predsednik Slovenskega društva v Stockholmu.

\section{Prebežništvo}

Poleg legalnih ekonomskih migracij so $\mathrm{v}$ drugi polovici 20. stoletja izseljevanje iz Slovenije (takrat Jugoslavije) na Švedsko (in drugam) zaznamovale tudi povojne ilegalne migracije. Te so se zmanjšale in legalizirale $\mathrm{z}$ Zakonom o amnestiji (1962) in s Sporazumom med SFR Jugoslavijo in Republiko Avstrijo o reguliranju zaposlovanja jugoslovanskih delavcev v Avstriji (1963) (Lukšič Hacin 2019) ter z nadaljnjimi bilateralnimi sporazumu (Svetek 1985). Vzroki za prebežništvo (in ekonomske migracije) so kompleksni in različni (prim. Zupančič, 2001; Japelj Carone, 2016; Mlekuž, 2019), prav tako izhodišča $\mathrm{v}$ izvorni državi in možnosti za vključevanje $\mathrm{v}$ ciljni državi. Kot kaže življenjska zgodba Slovenca iz Ilirske Bistrice, vzrok za prebežništvo po drugi svetovni vojni iz Jugoslavije ni bilo nujno nasprotovanje političnemu sistemu niti revno otroštvo. Ko je prišel na Švedsko kot prebežnik, je bil takoj vključen $\mathrm{v}$ usposabljanje in čez nekaj mesecev zaposlen. Njegova življenjska zgodba potrjuje ugotovitve Mirjam Milharčič Hladnik (2O20):

Čeprav je treba migracije vedno razumeti v širšem socialnem, kulturnem in političnem kontekstu, pa lahko o kompleksnosti vzrokov in motivov ter o načinih odhajanja mladih največ izvemo iz osebnih pričevanj akterjev povojnih migracij na Slovenskem. Mladih ne smemo videti (zgolj) kot žrtve povojnih okoliščin, pač pa kot aktivne akterje in avtonomne odločevalce. Razlogi [...] so bili zunanji, a hkrati osebni in intimni; odločitve hipne ali premišljene; odhodi pa dolgo načrtovani ali zgolj korak v neznano« (Milharčič Hladnik 2020: 163).

\section{Osebna izkušnja}

Anton Božič (rojen 1945) je preživel otroštvo v Trstu in v Ilirski Bistrici v vasi Vrbovo.' »Igrali smo nogomet, imeli smo se zelo lepo. Moja mladost

5 Navedbe Antona Božiča in njegove žene Eve Britt Božič, rojene Andreson, so iz ustne pripovedi, ki jo je posnela Marijanca Ajša Vižintin na Švedskem v Älmhultu 11. maja 2019 v okviru projekta »Socialna, gospodarska in kulturna zgodovina slovenskega izseljenstva (1945-91)«. Obširnejša življenjska zgodba bo (skupaj z drugimi življenjskimi zgodbami) objavljena v monografiji, ki sledi projektu, tu so povzeti le posamezni odlomki. Posnetke hrani avtorica. 
v Sloveniji je bila v redu, ni bilo težav. Imeli smo manjšo kmetijo, prašiče, kokoši, zajce, purane. Oče je delal na občini v Ilirski Bistrici, tako da se nismo imeli slabo, « je opisal svoje otroštvo Anton Božič. Končal je osnovno šolo in v Kopru naj bi se izučil za mehanika - a je leta 1964 prebegnil. Vzrok za prebeg je bil vpoklic v vojsko, in to za dve leti in pol. »Jaz sem rekel, da ne grem, «je bil odločen 18-letni Anton Božič. Doma nihče ni vedel za njegovo odločitev. Njemu je uspelo prvič, njegovemu prijatelju ne; ta je kasneje ponovno prebegnil in odpotoval v Avstralijo:

S prijateljem sva šla do Divače z vlakom. Potem sva našla mejo, sva videla, kje piše Italija, in tam je bila vojska, gotovo. Jaz sem se skril v luknjo, niti ni bila luknja, bolj jama, njega je ujel pes in vojaki so ga odpeljali. Streljali so v zrak, niso streljali na naju, ker bi naju lahko ubili. Govorili so »Stoj, stoj!«, ampak se nisem ustavil, odločil sem se pobegniti (Anton Božič, 2019).

Od maja do decembra 1964 so Antona Božiča premeščali po različnih italijanskih taboriščih, v katerih so se zbirali prebežniki. Razmere so bile

zelo slabe, preveč in preslabo je bilo v Italiji, in sem si rekel, da bom šel v prvo državo, ki nas bo sprejela. To je bila Švedska. Prišel sem v Älmhult in tukaj sem ostal. Njo, Evo, sem spoznal čez en teden in tako sva se dobila in še vedno živiva skupaj. $Z$ letalom smo šli do Malma, potem so nas z avtobusom poslali v Älmhult in tukaj sem ostal. Bilo nas je 274, ki smo prišli skupaj iz Italije na Švedsko. V Älmhultu smo ostali samo štirje, vendar ni bilo nobenega Slovenca, samo Hrvati, Srbi in jaz. Tu pa je bilo, kot da smo prišli v hotel. Prvič, ko sem jedel večerjo tukaj, smo dobili piščanca $\mathrm{z}$ marmelado, zelo lepo je bilo, vse očiščeno, sobe so bile zelo lepe. Samo hrana! Čudil sem se, kako lahko jejo piščanca $\mathrm{z}$ marmelado, ni bila marmelada, nekaj posebnega je bilo, ampak je bilo sladko kot marmelada, vendar ni prava marmelada. Ampak človek se privadi (Anton Božič, 2019).

Prve tri mesece na Švedskem je Anton Božič v Älmhultu obiskoval šolo za strugarja, potem pa so ga zaposlili v bližnji tovarni (1964-1969). V svoji prvi službi je dobil tudi švedske prijatelje, a je imel zanje malo časa; najpomembnejša mu je bila žena Eva: »Meni je bila najpomembnejša ona, da me je naučila švedsko in da sva ustvarila družino skupaj.« Delo strugarja Antonu Božiču ni bilo zanimivo, zato je leta 1969 odšel v eno izmed trgovin vprašat, ali potrebujejo kakšnega delavca. Zaposlili so ga poskusno za 
tri mesece - in v tej trgovini je ostal vse življenje, najprej kot trgovec, potem kot solastnik. Trgovino je vodil do leta 2009, ko se je upokojil. Prodajal je radie, kasetofone, videorekorderje, kamere in podobno, televizije in nudil servis zanje - ta storitev se Ikei (na srečo) ni obnesla.

Eva Britt Andreson je spoznala Antona Božiča, ko je bil kot prebežnik nastanjen v naselju, imenovanem Villa Siesta, blizu njenega doma. Ob večerih sta se sprehajala, vozila kolo in se pogovarjala. Takrat v Älmhultu in sploh na Švedskem še ni bilo veliko priseljencev, »bilo je zelo malo ljudi iz drugih držav, Madžari so prišli okoli leta 1965, Jugoslovani so prihajali od leta 1962 naprej, « je opisal razmere Anton Božič. Ko se je leta 1966 rodila prva hči Klavdija, so dobili manjše stanovanje. Pozneje so se preselili v večje in še v večje, leta 1981 pa sta kupila hišo, v kateri živita še danes. Eva je bila zaposlena v prvi trgovini Ikea, odprti leta 1958 v Älmhultu, ${ }^{6}$ od svojega 15. do 18. leta:

Delala sem v trgovini in pomagala kupcem, da so se znašli z Ikeinimi katalogi. Pri 18 letih sem rodila prvo hčerko, zato sem prenehala delati v Ikei. Malo mi je bilo nerodno, ker sem bila noseča tako mlada. Antona sem spoznala leta 1964, leta 1966 se je rodila prva hčerka Klavdija, poročila sva se leta 1970, ko sem bila noseča z drugim otrokom, z Niklasom. Imela sem še nekaj manjših zaposlitev, a potem so prišli otroci, Anton je bil v službi od jutra do večera in ostala sem doma. Rada sem bila doma $\mathrm{z}$ najinimi otroki (Eva Britt Božič, 2019).

Imata štiri otroke, tri hčere in sina, in osem vnukinj, vnukov, ki živijo na Švedskem, Norveškem ali na Filipinih. Leta 1969, pet let po prebegu, ko je dobil jugoslovanski potni list, je Anton Božič znova obiskal Slovenijo oz. Jugoslavijo. Dokler so bili otroci majhni, je Slovenijo družina Božič obiskovala enkrat ali dvakrat letno. V Vrbovem pri Ilirski Bistrici so obiskovali starše, dokler so živeli. Kasneje so poleti hodili na počitnice k sestri na Ko-

6 V Älmhultu so v prvi Ikeini prodajalni uredili muzej. Ima dve glavni temi: Ikea nekoč in Ikea danes. Ikea nekoč začne svojo pripoved z revno Švedsko, s skromnim življenjem in z borbo za preživetje na začetku 2o. stoletja: $\mathrm{z}$ majhnimi temnimi hišami, s še manjšimi okni, z leseno mizo, okrog katere se je zbralo okoli 10 otrok in jedlo iz ene glinene sklede $\mathrm{z}$ lesenimi žlicami - podobno kot na podeželju drugod po Evropi. Milijon Švedinj in Švedov se je v obdobju med prvo in drugo svetovno vojno izselilo čez lužo, kar potrjujejo veliki leseni kovčki in seznami čezoceanskih ladij v muzeju Ikea (prim. Beijbom 2003). V eno izmed švedskih izpraznjenjih hiš so se naselili stari starši ustanovitelja Ikee Ingvarja Kamprada, leta 1896 priseljena iz Nemčije in (današnje) Češke, nekoč Avstro-Ogrske (Torekull 2012: 27-43). 
zino ali pa v Iko blizu Opatije, kjer je živela sestrična. Na dopust so se odpeljali vsako poletje za tri tedne, saj je bil dopust na Švedskem takrat dolg štiri tedne, en teden pa vzame potovanje. Evropo so vsakič prepotovali sami, »Z avtomobilom ni tako daleč, brez spanja 24 ur, «je pojasnil Anton Božič. Vmes so počivali in prespali nekje v Nemčiji. Eva Božič je povedala, da so bile počitnice v Sloveniji njen najljubši dopust. Zadnjič je bil Anton Božič v Sloveniji leta 2016. S seboj je na Švedsko odnesel cepiče jablane, sadike trt in čebulice čemaža, kar jih je s ponosom pokazal med razkazovanjem svojega sadno-zelenjavnega vrta:

Vrtove imamo Slovenci, Hrvati in Grki, drugi imajo samo okrasno grmičevje in drevje. Sem v pokoju, jaz moram nekaj delati. To ni za to, da bi človek kaj zaslužil, to mi je v veselje. Stane več, kot je vredno, vendar je to zame zabava. Včasih pridejo na vrt srne in mi kaj pojejo. Kadar je suša, kot je bila 2018, je prepovedano zalivati vrtove; $z$ družbo ne gremo po gostilnah, tukaj ni veliko gostiln, tukaj je samo hotel Ikea. Ni gostiln, samo na kavo se lahko gre, popiješ sok ali pa pivo, alkohol se tukaj ne prodaja. Imaš posebno trgovino, samo eno v Älmhultu, v kateri lahko kupiš alkohol (Anton Božič, 2019).

V Älmhultu ni nobenega drugega Slovenca. Veliko je Hrvatov, nekaj Srbov, od razpada Jugoslavije naprej se je priselilo veliko Bošnjakov, »samo Slovenca ni niti enega. Bil je frizer, ampak je šel nazaj. Oba sta bil Slovenca, on je bil iz Maribora, imela sta sorodnike v Pulju in sta odšla; od takrat naprej ne vem za še kakšnega Slovenca tukaj, «je pojasnil Anton Božič na vprašanje, ali se druži z drugimi Slovenci. Posledično v Älmhultu ni nobenega slovenskega društva. V Olofströmu, ki je od Älmhulta oddaljen 50 $\mathrm{km}$, deluje najbližje slovensko društvo Slovenija in tudi srbsko, nekdanje jugoslovansko društvo. V slovenskem društvu imajo sestanke štirikrat letno, vendar se jih udeleži Anton Božič samo občasno, kajti veliko ljudi, ki jih je poznal, se je postaralo ali umrlo. Njegova morebitna udeležba je odvisna tudi od obiska otrok in vnukov, vnukinj; druženje z njimi ima prednost pred vsem.?

$7 \quad$ Za primerjavo: Janez Slabanja, rojen leta 1943, je prebegnil leta 1961, na Švedsko je prišel v skupini iz Avstrije. Namestili so jih v različne tovarne. Vse od začetka je delal kot vodovodni inštalater; dela takrat ni bilo težko dobiti. Državljanstvo je zamenjal leta 1968, naslednje leto je šel skupaj z družino v Slovenijo. Žena je obdržala slovensko državljanstvo, otroka imata švedsko državljanstvo. Hčerka rada hodi v Slovenijo, veliko si dopisuje, navezala je stike v Sloveniji. Sin nima stikov in noče hoditi v Slovenijo; pravi, da ga slovenstvo ne zanima. Oba otroka imata prijatelje med Švedi. 
Švedsko državljanstvo je Anton Božič pridobil že leta 1970: »Pet let moraš biti tukaj, ne smeš imeti težav s policijo in dobiš državljanstvo, « je pojasnil preprost postopek. Ni mu bilo treba opravljati izpita iz švedskega jezika in zgodovine. Slovenskega potnega lista nima več, dokumenti so mu potekli in ni si uredil novih. Včasih gleda slovensko televizijo, kar mora posebej plačati.

Ko je prišel Anton Božič v Älmhult, je bilo to majhno mesto. Zaradi zaposlitvenih priložnosti v Ikei se je v mesto preselilo veliko ljudi, z odprtjem muzeja Ikea (2016) in prenovljenega hotela Ikea prihajajo turisti. Priseljujejo se novi begunci, zdaj iz Sirije in Libanona, a zanje »ni več tako lahko tukaj kot takrat, ko smo mi prišli, ni dela, moraš govoriti jezik. Če govorijo angleško, je še v redu, če govorijo samo arabsko, pa zelo težko dobijo delo,« (Anton Božič, 2019).

\section{Nekaj predlogov za obravnavo slovenskih migracij pri pouku}

Še preden bodo v slovenskih učnih načrtih in gradivih zapisani učni cilji, ki bodo naslavljali slovenske migracije, tako izseljevanje kot priseljevanje, učiteljicam in učiteljem svetujem, da sami zbirajo gradivo. V razredih lahko spregovorijo o izseljevanju in preseljevanju, tako v preteklosti kot v sedanjosti; o beguncih in ekonomskih migrantih; o ohranjanju maternega jezika in učenju jezika okolja; o književnih besedilih, ki tematizirajo migracije; o izzivih sestavljene identitete in spreminjajoči se kulturi; o oblikovanju nacionalnih držav v 19. stoletju itd. (Vižintin 2017). Pri odpiranju zapletenih migracijskih tem si lahko pomagajo tudi s sodobnimi priročniki, npr. $A B$ CČĆ migracij (Mlekuž 2021), Migracijski pojmovnik za mlade (Toplak 2019).

Učiteljice, učitelji lahko skupaj z učenci, učenkami zbirajo osebne življenjske zgodbe priseljenih in izseljenih, kot je v prispevku prikazano na primeru izseljenca Antona Božiča: kratek opis družbeno-političnih razmer v izvorni in sprejemni državi, ki so o(ne)mogočale izseljevanje ali priseljevanje v določenem časovnem obdobju ter življenjska zgodba. Učenke, učenci lahko svoje izseljene sorodnike, sorodnice povprašajo: kam, zakaj in kdaj so se izselili; kako in koliko časa je potekalo učenje jezika okolje, vključevanje v sprejemno družbo; kateri so bili kulturni šoki; kako pogosto se vračajo v izvorno deželo, ali se nameravajo kdaj za stalno vrniti; ali so dejavni v katerem od kulturnih društev; ali obiskujejo dopolnilni pouk

Janez Slabanja ima prijatelje med Slovenci in Švedi. Živi približno 60 km iz Göteborga, v katerem je slovensko društvo, društvenih dejavnosti pa se udeležuje zadnja tri leta (Lukšič Hacin 2001: 164-169). 
maternega jezika in kulture; ali so bili kdaj diskriminirani in kako so se ob tem počutili; kako je potekalo urejanje dokumentacije, pridobivanje državljanstva itd. Ista vprašanja lahko postavijo priseljencem, priseljenkam v svojem lokalnem okolju.

Mogoče bi bilo lažje začeti z že obstoječimi zbirkami življenjskih zgodb, npr. iz zbirk Zgodbe in pričevanja: Slovenci na Švedskem (Lukšič Hacin, 2001), Krila migracij: Po meri življenjskih zgodb (Milharčič Hladnik, Mlekuž, 2009), IN-IN: Življenjske zgodbe o sestavljenih identitetah (Milharčič Hladnik 2011) ali iz tretjega poglavja (Življenjske zgodbe) v monografiji Doba velikih migracij na Slovenskem (Kalc, Milharčič Hladnik, Žitnik Serafin, 2020), ki jih potem učiteljice, učitelji obravnavajo $z$ učenkami, učenci. Pri tem lahko pri pouku odpirajo številne teme, tesno povezane z migracijami, predlagam pa, da raziščejo tudi dejstva, ki jih ponujajo številke oz. uradni statistični podatki.

Če so učiteljicam, učiteljem bližje literarizirane življenjske zgodbe otrok, imajo na voljo kar nekaj slovenskih in v slovenščino prevedenih mladinskih književnih besedil (Vižintin 2018a), ki prikazujejo usode otrok v migracijskih procesih. Obravnavajo jih lahko pri pouku slovenskega jezika in književnosti ter pri pouku drugih jezikov, če izhajajo iz izvirnikov.

\section{Zaključek}

Migracije so stalnica, a se pri pouku premalo obravnavajo. Prispevek razvija izseljensko-priseljensko perspektivo in predlaga vsebine, ki se lahko obravnavajo pri pouku. Kot primer vsebuje slovensko izseljensko zgodbo Antona Božiča, ki se je izselil na Švedsko, in opis slovenske organiziranosti na Švedskem. Cilj obravnavanja migracijskih pojavov pri pouku je ozaveščanje migracijskih procesov kot stalnega družbenega pojava, predvsem pa ozaveščanje dejstva, da je Slovenija tako dežela izseljevanja kot priseljevanja. Cilj je tudi preseganje predsodkov do priseljencev, priseljenk v Sloveniji, kajti slovenske izseljenke, izseljenci so - priseljenke, priseljenci nekje drugje. Prispevek vabi pedagoške delavke, delavce, da spodbudijo svoje učenke in učence, dijakinje in dijake, študentke in študente ter njihove starše k raziskovanju migracij znotraj svojih družin in v lokalnem okolju, predvsem pa k njihovi predstavitvi znotraj vzgojno-izobraževalnega procesa. 


\section{Literatura in viri}

Anderson, Benedict R. O‘G. Zamišljene skupnosti: o izvoru in širjenju nacionalizma, Ljubljana: Studia humanitatis, 1998.

Beijbom, Ulf. Images of Swedish-America, Växjö: Emigrant Institute Friendship Society, 2003.

Božič, Anton in Eva Britt Božič. »Življenjska zgodba Antona Božiča«. Posneto v okviru projekta Socialna, gospodarska in kulturna zgodovina slovenskega izseljenstva (1945-91), 2019.

Budja, Avguština (ur.). Slovenci na Švedskem: okvirno zgodovinski pregled: monografija = Slovener $i$ Sverige: I ett globalhistoriskt perspektiv: monografi. Landskrona: [samozal.], 2005.

Dimkovska, Lidija (ur.). Iz jezika v jezik: antologija sodobne manjšinske in priseljenske književnosti v Sloveniji, Ljubljana: Društvo slovenskih pisateljev, 2014.

Drnovšek, Marjan. Slovenski izseljenci in zahodna Evropa v obdobju prve Jugoslavije, Ljubljana: Založba ZRC, ZRC SAZU, 2012.

Japelj Carone, Liza (ur.). Mi, ki smo odšli: Pričevanja pariških Slovencev povojne generacije. Korenine, februar 2016.

Kalc, Aleksej, Mirjam Milharčič Hladnik in Janja Žitnik Serafin. Doba velikih migracij na Slovenskem, Ljubljana: Založba ZRC, ZRC SAZU, 2020.

Kobolt, Alenka. Zdej smo od tu - a smo še čefurji? Ljubljana: i2, 2002.

Komac, Miran. Priseljenci: študije o priseljevanju in vključevanju v slovensko družbo, Ljubljana: Inštitut za narodnostna vprašanja, 2007.

Lukšič Hacin, Marina. Ko tujina postane dom: resocializacija in narodna identiteta pri slovenskih izseljencih, Ljubljana: Znanstveno in publicistično središče, 1995.

Lukšič Hacin, Marina. Zgodbe in pričevanja: Slovenci na Švedskem, Ljubljana: Založba ZRC, ZRC SAZU, 2001.

Lukšič Hacin, Marina. „Selitvena dinamika slovenskega prostora v zgodovinski perspektivi.«Dve domovini/Two Homelands, št. 48 (2018): 55-72.

Lukšič Hacin, Marina. »Političnost migracij po drugi svetovni vojni: Od politike revanšizma do amnestije«. Dve domovini/Two Homelands, št. 50 (2019): 183-198.

Milharčič Hladnik, Mirjam in Jernej Mlekuž (ur.). Krila migracij: Po meri življenjskih zgodb, Založba ZRC, ZRC SAZU, 2009. 
Milharčič Hladnik, Mirjam (ur.). IN-IN: življenjske zgodbe o sestavljenih identitetah. Ljubljana, Založba ZRC, ZRC SAZU, 2011.

Milharčič Hladnik, Mirjam. »Kultura mešanosti v nacionalnem in migracijskem kontekstu«. Annales, Series historia et sociologia, št. 25(1) (2015): 171182.

Milharčič Hladnik, Mirjam. »Kolektivna izkušnja prebežništva in drugih oblik izseljevanja mladih po drugi svetovni vojni v pisnih, ustnih in drugih avto/biografskih virih."Dve domovini/Two Homelands, št. 51 (2020): 151-166.

Mlekuž, Jernej. »Nadzor nad nenadzorovanimi migracijami: kako je slovensko časopisje pisalo o prebegih iz Jugoslavije v letih 1945-1965." Dve domovini/Two Homelands, št. 50 (2019): 163-182.

Mlekuž, Jernej. ABCČĆ migracij, Ljubljana: Založba ZRC, 2021.

Pogačnik, Marko idr. 6. Srečanje slov. društev zah. Evrope 1978: Velika kulturna in športna manifestacija slovenskih društev zahodne Evrope 10. 6. 1978 $v$ svetovno znani dvorani Jahrhunderthalle, Frankfurt/M: Slovensko kulturno prosvetno društvo Sava, 1978.

Sedmak, Mateja. »Kultura mešanosti. Družbeno in politično prepoznavanje socialne kategorije mešanih ljudi." Annales, Series Historia et Socilogia, št. 21(2) (2011): 261-274.

Svetek, Lev. Pravice in dolžnosti: socialna in ekonomska varnost naših delavcev na tujem. Ljubljana: Delavska enotnost, 1985.

Toplak, Kristina. Migracijski pojmovnik za mlade. Maribor: Aristej, 2019.

Torekull, Bertil. The Ikea story: Ingvar Kamprad, Litopad: Ikea family, 2012.

Verginella, Marta. Suha pašta, pesek in bombe: Vojni dnevnik Bruna Trampu$z ̌ a$, Koper: Univerza na Primorskem, Znanstveno-raziskovalno središče, Zgodovinsko društvo za južno Primorsko, 2004.

Vižintin, Marijanca Ajša. »(Im)migrant and ethnic minority literature in education curricula in Slovenia.«. CLCWeb: comparative literature and culture, št. 8(1), (2016a), https://doi.org/10.7771/1481-4374.2763.

Vižintin, Marijanca Ajša. »Slovenski izseljenci in njihovi potomci v Nemčiji: dvajset let povezovanja slovenskih organizacij na posvetih." Dve domovini/Two Homelands, št. 43 (2016b): 157-170.

Vižintin, Marijanca Ajša. Medkulturna vzgoja in izobraževanje: Vključevanje otrok priseljencev, Ljubljana: Založba ZRC SAZU, 2017.

Vižintin, Marijanca Ajša. »Brati in spregovoriti: o migracijah ob mladinskih književnih besedilih.« Otrok in knjiga, št. 102 (45) (2018a): 8-22. 
Vižintin, Marijanca Ajša. »Developing intercultural education.« Dve domovini/Two Homelands, št. 47 (2018b): 89-106.

Vižintin, Marijanca Ajša, Marina Lukšič Hacin in Maja Gostič. Samo visoko izobraženi se izseljujejo. Pa je to res?: zaključno poročilo, Ljubljana: Založba ZRC, 2020.

Zupančič, Jernej. »Slovensko izseljenstvo v Evropi po drugi svetovni vojni.« V Slovensko izseljenstvo: zbornik ob 5o-letnici Slovenske izseljenske matice, 291-299. Ur. Milica Trebše Štolfa, Matjaž Klemenčič. Ljubljana: Združenje Slovenska izseljenska matica. 2001.

Žitnik Serafin, Janja in Helga Glušič (ur.). Slovenska izseljenska književnost. 1: Evropa, Avstralija, Azija, Ljubljana: ZRC, Rokus, 1999.

\section{Spletne strani}

Doljak, Eva. »Maja Keuc o Švedski: Pogrešam toplino Slovencev.«SiolNET, Novice, Slovenci v tujini. https://siol.net/novice/slovenci-v-tujini/maja-keuc-o-svedski-pogresam-toplino-slovencev-467907 (14. 12. 2020).

Dopolnilni pouk 2019/20. Zavod Republike Slovenije za šolstvo. https://www. zrss.si/sticisce/dopolnilni-pouk/ (14. 12. 2020).

Hrastar, Mateja A. »Alojz Macuh, predsednik slovenskega društva Simon Gregorčič v Köpingu: Švedsko govorijo le, kadar dobijo švedske obiske.« Dnevnik, Slovenci po svetu, https://www.dnevnik.si/1042877016 (14. 12. 2020).

Hrastar, Mateja A. »Rok Ogrin, prometni inženir na Švedskem: Za kavo in pecivo odložiš delo.«Dnevnik, Slovenci po svetu, https://www.dnevnik. $\mathrm{si} / 1042831853$ (14. 12. 2020).

Krivec, Vasilij. »Predstavljamo slovensko inženirko, ki na Švedskem vodi gradbišče 94 stanovanj: Gradbena inženirka Maja Golubovič je bila ena izmed nominirank za inženirko leta 2018.«Finance.si. https:/gradbenistvo.finance.si/8943561/Predstavljamo-slovensko-inzenirko-ki-na-Svedskem-vodi-gradbisce-94-stanovanj?cctest\& (14. 12. 2020).

Le $z$ drugimi smo (2016-2021). ZRC SAZU, Inštitut za slovensko izseljenstvo in migracije, Pedagoški inštitut, https://lezdrugimismo.si/ (14. 12. 2020).

Macuh, Alojz. Slovenska zveza na Švedskem, Köping. http://www.slovenskazvezanasvedskem.com/o-nas.html (14. 12. 2020).

Nakrst, Katja. "Zala iz Švedske: Kdor se pritožuje zaradi hladnih Švedov, naj pride na zaključek naših produkcij."SiolNET, Novice, Slovenci v tujini. https://siol.net/novice/slovenci-v-tujini/zala-iz-svedske-kdor-se-pritozu- 
je-zaradi-hladnih-svedov-naj-pride-na-zakljucek-nasih-produkcij-481175 (14. 12. 2020).

Osebe s priznano mednarodno zaščito po letih. Poročila. Urad Vlade Republike Slovenije za oskrbo in integracijo migrantov. https:/www.gov.si/assets/ vladne-sluzbe/UOIM/STATISTIKA/Januar-2020/Osebe-s-priznano-mednarodno-zascito-po-letih-12-2019-v3.pdf (14. 12. 2020).

Selitveno gibanje Slovenija, 2017. Statistični urad Republike Slovenije. https:// www.stat.si/StatWeb/News/Index/7837 (14. 12. 2020).

Socioekonomske značilnosti meddržavnih selivcev Slovenija, 2017. Statistični urad Republike Slovenije. https://www.stat.si/StatWeb/News/Index/7837 (14. 12. 2020). 